\title{
RIBA DAN BUNGA BANK DALAM PANDANGAN IBN QAYYIM DAN RELEVANSINYA DENGAN PERKEMBANGAN PERBANKAN ISLAM
}

\author{
Siti Khayisatuz Zahroh \\ Dosen STAIDU Darul Ulum Berasan Banyuwangi \\ E-mail: hadiari701@yahoo.com
}

\begin{abstract}
Abstrack
This research is based on library research which focus on discussing the problem that has existed since classical times, this discussion is a discussion of the concept of usury and bank interest in the view of IbnQayyim al-Jawziyya. Contemporary cleric is a cleric who often argue controversial, especially in discourses in the form of a controversial study. In this issue of this paper deals theview of IbnQayyim about riba at the time of the Prophet Muhammad until the time of IbnQayyim life. How interpretation riba second word in the Qur'an that until now remain in debateble between the ulama interpretation and jurisprudence specially byIbnQayyim own, third riba what if the opinion in view of IbnQayyim in relate with the view evolving Bank Interest in the modern world. The results of this study is that the definition of usury and interest in the view of IbnVayyim has differed fundamental. Secondly, that the bank interest now grown not purely as said riba during Nab Muhammad. Third IbnVayyim has the opinion that one and two were associated with a more contextual understanding of the interpretation in the life of the complex at this time.
\end{abstract}

Keywords: Riba, Bank,andIbnQoyyim.

\begin{abstract}
Abstrak
Penelitian ini adalah penelitian berbasis library reseach yang fokus membahas dalam masalah yang sudah ada sejak zaman klasik, pembahasan ini adalah pembahasan tentang konsep Riba dan Bunga Bank dalam pandangan Ibnu Qayyim al-Jauziyyah. Ulama Kontemporer ini merupakan Ulama yang sering berpendapat kontroversial, apalagi pada wacana-wacana berupa kajian yang kontroversial. Dalam masalah ini paper ini berkutat pada bagimana pandangan Ibnu Qayyim tentang Riba pada masa Nabi Muhammad SAW sampai Riba pada masa Ibnu Qayyim hidup. Kedua Bagaimana penafsiran Kata Riba dalam al-Qur'an yang semapai sekarang tetap dalam debateble diantara kalangan Ulam tafsir dan fiqh terutamaoleh Ibnu Qayyim sendiri,ketiga bagaimana apabila pendapat Riba dalam pandangan Ibnu Qayyim di sangkutkan dengan pandangan Bunga Bank yang berkembang pad dunia moderen. Adapun hasil dari penelitian ini adalah bahwa yang dimaksud dengan riba dan bunga bank dalam pandangan Ibnu 2ayyim mempunyai berbedaan yang mendasar. Kedua, bahwa bunga bank yang sekrang berkembang bukan dikatakan murni sebgaia Riba dalam masa Nab Muhammad SAW. Ketiga bahwa Ibnu Qayyim mempunyai pendapat satu dan dua itu berkaitan dengan pemahaman tafsir yang lebih kontekstual dalam kehidupan yang komplek pada saat ini.
\end{abstract}

Kata Kunci: Ibnu Qayyim, ribadan bunga bank. 


\section{A. Pendahuluan}

Pro dan kontra tentang hukum bunga bank yang terkait dengan riba bukan saja terjadi dikalangan sarjana muslim, akan tetapi juga pemikir non muslim, sebab itulah ada beberapa ilmuan ahli filsafat yang juga mengharamkan riba. Plato misalnya, dalam bukunya The Law of plato, menegaskan bahwa orang tidak boleh meminjamkan uang dengan rente, dan Aristoteles juga menyatakan dengan hal tersebut. Di dalam bukunya Al-Siyasah, bahwa uang adalah alat jual beli, sementara hutang adalah hasil dari jual beli, sedangakan bunga (rente) adalah uang yang lahir dari uang. Menurutnya, seseorang yang meminjamkan uang dengan rente merupakan pekerjaan hina dan kita, katanya wajib menolaknya (Atawi, 1988).

Syariat agama Yahudi juga mengharamkan praktek riba, dalam Taurat juga di jelaskan "Janganlah kalian meminjam uang kepada saudaramu sesama Israel dengan cara riba, berupa perak emas, makanan atau apa saja yang bisa dipinjamkan dengan riba, agar Rabb Tuhanmu memberikan berkat kepada setiap usahamu (Iamuddin, 1995).

Murtadha Munthari juga berpendapat bahwa dalam kajian filsafat, ia menyatakan riba adalah bentuk pencurian, karena uang tidak bisa melahirkan uang. Uang tidak memiliki fungsi lain selain alat tukar, uang itu sendiri tidak dapat memebri keuntungan dan sebenarnya uang itu mandul, dan ini sebenarnya adalah hakekat dalam kajian riba (Munthari, 1995: 18).Memang dalam perjalanan agama Islam ulama membagi riba menjadi dua, pertama, riba nasi'ah, sedangkan kedua riba fadl. Tokoh sahabat dan tabi'in memperbolehkan riba fadl, yang kelebihan harga transaksinya barang bukan karena penundaan atau penyegeraan pembayaran.Para tokoh tersebut misalnya Ibnu Abbas, Zaid Bin Arqam, Ikrimah, dan lain sebgainya. Sedangkan para pakar tafsir yang juga memperbolehkan riba fadl adalah kalangan Abu Ja'far Muhammad bin Jarir At-Tabari, Muhammad Abduh (Ridha 1374: 102-104), yang menjadi unik adalah salah satu ulama sekaliber Ibn al-Qayyim Jauziyyah, dia membagi riba menjadi dua macam, pertama, riba jali, dan kedua, riba khafi. Riba jali adalah riba yang mengandung kemudharatan besar, sedangkan riba khafi adalah riba yang mengandung atau kalau dilakukan membawa praktek ke riba jali (Jauziyah, tt: 135).

Ibn Qayyim menegaskan bahwasanya dasarnya riba diharamkan, dalam kondisi tertentu menurutnya bisa ditolerir, adanya tolerir dalam kondisi pertama, untuk riba jali dalam kondisi darurat, sedangkan kedua, riba khafi diperbolehkan dalam kondisi hajat (Jauziyah, tt: 138-9). Jelas, apayang dikemukan oleh Ibn Qayyim ini berbeda dengan ulama-ulama pendahulunya. Yang tidak membuka peluang sama sekali dengan konsep riba. Maka dalam adagium fiqh mereka sedikit atau banyak kalau itu riba tetap haram,melihat pemikiran Ibn Qayyim yang unik ini, menjadi dasar dari penulisan ini, bagaimana nalar ijtihad dan penafsiran terhadap ayat-ayat riba dalam pandangan Ibn Qayyim. Lebih lagi kalau pendapat ini kita lempar dalam suasana wacana perbankan Islam yang berkembang pesat di hari ini, warna pemikiriran Ibn Qayyim ini 
menjadi hal yang penting dalam memberikan khazanah keilmuan dan pandangan baru dalam memaknai riba, dalam kontek skala global.

\section{B. Biografi Ibn Qayyim}

Nama lengkap beliau adalah Muhammad Bin Abu Bakr Ibn Ayyub Ibn Sa'ad Ibn Hariz al-Zar'i al-Dimasyqi al-Hanbali. Laqabnya adalah Syams alDin dan Kunyahnya Abu Abdillah (Jauziyyah, 2004: 3). Namun beliau lebih terkenal dengan sebutan Ibn Qayyim al-Jauziyyah, sebab ayahnya adalah seorang pengurus sekolah alJauziyyah (Jauziyah, 1998: xix).

Julukan Ibn al-Jauzy sebenarnya tidak tepat kalau disandarkan kepada Ibn Qayyim. Sebutan ini muncul dan populer dikarenakan keteledoran para penulis atau orang-orang yang tidak suka kepada Ibn Qayyi<m, karena julukan Ibn al-Jauzy diberikan kepada Abd al-Rahman Ibn Ali al-Quraisy yang wafat pada tahun $596 \mathrm{H}$. Di samping itu ada juga beberapa orang yang mempunyai julukan Ibn Qayyim alJauziyyah. Mereka tidak lain adalah orang yang memiliki nasab yang sama dengan ayahnya yang bernama Abu Bakr Ayyub, yakni saudara kandung Ibn Qayyim (Muhammad Ibn Abu Bakr) (Sanhuti, 200l: 20). Sedangkan beberapa orang yang menyamai julukan Ibn Qayyim adalah dua orang yang sama alimnya, yaitu:pertama, Ibn Qayyim alHanbali, adalah Abu Bakr Muhammad ibn Ali Ibn Husain Ibn Qayyim alHanbali. Beliau termasuk golongan ulama ahli hadits dan wafat tahun 480 H. Kedua, Ibn Qayyim al-Misri, adalah Ali Ibn Isa Ibn Sulaiman al-Salabi alSyafi'i Ibn Qayyim. Beliau dikenal sebagai muhaddis dan juga perawi. Wafat tahun $710 \mathrm{H}$.
Ibn Qayyim al-Jauziyyah lahir pada 7 Safar 691 H/1292 M. Mayoritas ulama mengatakan bahwa beliau dilahirkan di kota Damaskus, Siria. Namun ada pula yang mengatakan bahwa beliau dilahirkan di desa Zar'i, Hauran, yang terletak di sebelah Timur kota Damaskus. Beliau wafat pada usia 60 tahun, tepatnya malam Kamis 13 Rajab 751 H./1350 M., waktu azan Isya di kota Damaskus. Jenazahnya dimakamkan di pemakaman al-Bab alSaghir di samping makam orang tuanya (Dimasyqi, 1987: 246). Beliau berasal dari kalangan terhormat dan tumbuh dalam lingkungan keluarga yang taat dan berilmu. Ayahnya, selain sebagai seorang pendidik juga dikenal sebagai seorang ulama fiqh Hanbali yang ahli dalam bidang fara'id. Dari sinilah beliau memulai perjalanan intelektualnya.

Selain ahli dalam berbagai masalah agama, beliau pun sangat ahli dalam masalah akhlak dan sastra. Beliau memiliki wawasan tentang metodologi pembentukan dan terapi jiwa. Beliau menjadikan Rasulullah saw. sebagai panutan dan selalu menerapkan etika dan adab kenabian dalam dirinya. Etika kenabian ini beliau terapkan dalam sikap yang baik dan jiwa yang bersih. Hal ini dapat dilihat ketika beliau mengatakan dalam kitabnya Madarij alSalikin, bahwa jika ada orang lain berbuat buruk kepadamu kemudian orang tersebut meminta maaf kepadamu, maka kamu wajib memaafkannya tanpa melihat apakah dia salah atau benar, kemudian serahkanlah maksud hatinya kepada Allah swt (Jauziyyah, 1992: 337).

Kehidupan Ibn Qayyim dalam mengisi aktivitas sehari-harinya tidak jauh dari kreatifitas ilmiahnya. Sepanjang hidupnya beliau curahkan 
untuk menulis kitab dan mengajar di berbagai madrasah di Damaskus. Seperti yang telah diketahui, Damaskus ketika itu menjadi pusat kajian keilmuan yang sangat terkenal dan penuh dengan forum-forum ilmiah yang diselenggarakan oleh para ulama. Beliau juga menggantikan kedudukan ayahnya menjadi pimpinan Madrasah alJauziyyah yang didirikan oleh ayahnya sendiri dalam waktu yang cukup lama.

Berdasarkan periodisasi sejarah Islam, Ibn Qayyim hidup pada abad pertengahan (1250-1800 M.), tepatnya ketika dinasti Mamluk (1250-1517 M.) berkuasa di Mesir dan Siria, yaitu pada masa pemerintahan Salah al-Din Khalil (1290-1294 M.) hingga masa Nasir alDin al-Hasan (1347-1351 M.). Pada periode tersebut, secara umum umat Islam sedang mengalami masa kemunduran, baik dalam bidang politik maupun sosial keagamaan (Nasution 1985: 79).Dalam bidang politik, umat Islam sedang mengalami dua masalah besar. Pertama, disintegrasi politik dalam negeri dan kedua, bahaya serangan dari kaum Nasrani dan bangsa Mongol. Para Khalifah Abbasiyah (750-1258 M.) yang berpusat di Baghdad ternyata tidak mampu mempertahankan kedaulatan wilayah kekuasaannya. Terjadinya disintegrasi politik dalam tubuh umat Islam tersebut menunjukkan adanya tiga hal. Pertama, adanya dipolarisasi antara dua kekuasaan besar, yakni Abbasiyyah di Timur dan Umayyah di Barat. Kedua, adanya fanatisme kebangsaan ('ashabiyyah) antara bangsa Arab dengan non Arab (mawalli), khususnya Persia dan Turki. Ketiga, adanya persaingan mazhab terutama antara Sunni dan Syi'ah (Nasution, 1985: 6).
Sementara itu, kekacauan di dalam negeri-negeri Islam ketika itu membuat mereka lengah terhadap bahaya dari luar. Kaum Nasrani merasa dendam terhadap umat Islam akibat kekalahannya dalam peristiwa Manzikart (1971 M). Sebagian besar unsur kekuatan Eropa ikut serta dalam penyerangan terhadap negeri-negeri Islam. Pada periode pertama, Palestina dan beberapa negeri Islam lainnya berhasil direbut oleh pasukan Salib. Namun pada beberapa tahun kemudian, tentara Islam yang dipimpin oleh Salah al-Din al-Ayyubi (1169-1193 M.), pendiri dinasti Ayyubiyah (1169-1250 M.), dapat merebutnya kembali dalam sebuah peperangan di Hittin pada tahun 1187 M. (Nasution, 1985: 77-79). Di pihak lain, pasukan Mongol berhasil merebut kekuasaan pusat dan menghancurluluhkan kota Baghdad pada tahun 1258 M. Namun kemudian gerak maju mereka dihadang oleh tentara Islam yang dipimpin oleh alZahi Baybars (1260-1277 M.) dari dinasti Mamluk dalam peperangan besar di Ain Jalut, Palestina, pada tahun 1260 M. (Awad, 2002: 76-85).

Satu demi satu negeri Islam berhasil direbut dan dihancurkan. Hanya Mesir lah yang selamat dan dapat mempertahankan diri dari kehancuran. Pasukan Mamluk telah berhasil menyelamatkan Mesir dan Siria dari serangan pasukan Salib dan bangsa Mongol. Keberhasilan tersebut telah menjamin keamanan dalam negeri Mesir khususnya dan negeri-negeri Islam lainnya sampai beberapa abadselanjutnya (Awad, 2002: 76). Demikianlah situasi politik yang melatarbelakangi kehidupan Ibn Qayyim. Masa kecil beliau diliputi oleh peperangan dan kekacauan. Pada saat 
terjadinya peperangan besar di Syaqhab, Damaskus, pada tahun 1303 M. antara pasukan Mongol yang dipimpin oleh Mahmud Ghazan (1295-1304 M.) dengan tentara Mamluk yang dipimpin oleh Muhammad ibn Qalawun, usia beliau baru sekitar sebelas tahun (Hasan, 1989: 319). Saat itu umat Islam hidup dalam ketegangan politik. Sifat egois dan fanatis telah merasuki jiwa mereka kembali.

Dalam bidang sosial, secara umum kehidupan umat Islam pada saat itu juga sedang mengalami kemunduran, walaupun pada beberapa segi kehidupan mengalami kemajuan. Pada masa dinasti Mamluk berkuasa, telah dibangun beberapa sarana umum untuk menunjang kehidupan masyarakat, seperti sekolah, masjid, rumah sakit, perpustakaan, museum, dan lain-lain (Yatim, 2002: 128). Pemerintah pun memberikan kebebasan kepada para penganut mazhab untuk mengembangkan ajarannya. Namun demikian, umat Islam sedang mengalami kejumudan dalam berpikir. $\mathrm{Hal}$ ini disebabkan karena pendapat yang mengatakan bahwa pintu ijtihad telah tertutup diterima secara luas oleh masyarakat, sehingga menyebarlah sikap taqlid dan fanatik yang berlebihan, khususnya terhadap mazhab yang empat (Nasution, 1985: 83).

Ibn Qayyim yang terdidik dalam lingkungan salafi yang sangat memegang teguh aqidah para al-Salaf alShalih. Beliau banyak mengkritik metode takwil yang dilakukan oleh aliran rasionalis. Selain itu, beliau juga banyak mencela pemikiran-pemikiran mereka yang menurutnya telah menyimpang dari manhaj yang benar. Di pihak lain, gerakan tarekat sufi semakin bertambah luas di kalangan masyarakat. $\mathrm{Hal}$ ini turut ditunjang dengan dibangunnya tempat-tempat khusus oleh pemerintah untuk menampung para sufi dalam menyebarkan ajaranajaran mereka. Mereka mengembangkan konsep takwa dengan mengisolasi diri dari masyarakat dan hanya mengkhususkan diri dengan ibadah-ibadah ritual semata.

Di samping itu, mereka juga banyak menciptakan ritual-ritual aneh untuk mendekatkan diri kepada Allah swt. dengan melakukan tarian-tarian dan nyanyian-nyanyian tertentu yang mereka anggap sebagai bagian dari zikir (Nasution, 1985: 89-90). Ibn Qayyim dalam beberapa karyanya banyak mengkritik konsep-konsep tasawwuf dan praktek-praktek bid'ah yang mereka lakukan, salah satunya dalam kitab Madarij al-Salikin. Demikianlah situasi sosial umat Islam ketika itu. Sebagian besar hidup beliau dihabiskan untuk meluruskan berbagai penyimpangan pemikiran ahli kalam, kaum sufi, para filosof, dan berbagai bid'ah yang berkembang di masyarakatnya. Karya-karya beliau merupakan respon kritis terhadap perkembangan pemikiran pada masanya. Di sana terlihat jelas betapa besar perhatian beliau terhadap kemaslahatan umat.

Ibn Qayyim al-Jauziyyah telah memperlihatkan bakat intelektualitas, pemikiran yang cemerlang, dan semangat yang tinggi dalam menuntut ilmu. Beliau pun tumbuh dalam lingkungan yang kesehariannya dipenuhi dengan aktifitas ilmiah. Berbagai sekolah keagamaan yang khusus mengajarkan ilmu fiqh, hadis, dan kalam banyak tersebar di Mesir dan Siria ketika itu. Di antara sekolah- 
sekolah tersebut yang secara langsung berhubungan dengan aktifitas ilmiah beliau adalah sekolah al-Jauziyyah dan al-Sadriyyah (Uwaidhah, tt: 14). Pendidikan beliau dimulai bersama ayahnya di sekolah al-Jauziyyah, di samping beliau pun aktif belajar di sekolah-sekolah lain yang tersebar di daerahnya. Kemudian beliau menimba ilmu dari ulama-ulama terkemuka dan ahli pada masanya dalam berbagai bidang. Beliau pernah menetap di Mekah untuk belajar di sana, sekaligus untuk menunaikan ibadah haji (alImad: 169).

Beliau sangat tekun menelaah kitab-kitab warisan para ulama, terutama karangan Imam Ahmad ibn Hanbal dan Ibn Taimiyyah. Beliau juga gemar mengoleksi kitab-kitab tersebut untuk keperluan studi dan perpustakaan pribadinya. Jumlah koleksi beliau sangat banyak dan jarang sekali orang yang mampu menyainginya (Kasir: 248). Bahkan menurut Ibn Hajar al-Asqalani, setelah Ibn al-Qayyim wafat, anak-anaknya menjual sebagian koleksi ayahnya tersebut hingga beberapa tahun lamanya (Sanhuti: 28).

Beliau belajar kepada para ulama terkemuka dan ahli dalam bidangnya. Sebagian besar dari mereka bermazhab Hanbali, namun ada juga yang bermazhab Syafi'i. Di antara mereka adalah (Jauziyyah, 1998: xix-xx): Dalam bidang hadis: al-Syihab al-Nabilisi alAbir, al-Qadi Taqi al-Din ibn Sulaiman, Isma'il ibn Maktum, Isa al-Mat'am, Abu Bakr ibn Abd al-Da'im, dan Fatimah bint Jauhar.Dalam bidang bahasa: Ibn Abi al-Fath al-Ba'li dan Majd al-Din alTunisi.Dalam bidang fiqh dan ushul: Muhammad Safi' al-Din al-Hindi alSyafi'i, Taqi' al-Din Ahmad ibn Taimiyyah, dan Isma'il ibn Muhammad al Harani.Guru-gurunya yang lain: Ahmad ibn al-Syirazi, Ala' al-Din alKindi, Muhammad ibn Abi al-Fath, Ayyub ibn Kamal, Badr al-Din ibn Jama'ah al-Syafi'i, Abu> al-Fath alBa'labaki, Kamal al-Din al-Zamlakani, al-Mizzi al-Syafi'i, al-Muflih, dan Syaraf al-Din ibn Taimiyyah (Jauziyah: 3). Di antara guru-guru beliau yang paling banyak memberikan pengaruh pada perkembangan intelektualnya adalah Syaikh al-Islam Ibn Taimiyyah (661-728 H/1263-11328 M). Beliau selalu menyertainya sejak kepulangannya kembali dari Mesir ke Damaskus pada tahun 712 H. hingga beliau wafat. Sejak itu beliau banyak menimba ilmu darinya dan berjuang bersamanya dalam memerangi berbagai pemikiran yang menyimpang dan praktek-praktek bid'ah (Kastir: 246).

Pengaruh pemikiran gurunya itu sengat jelas terlihat dalam berbagai karya tulis beliau. Lebih dari itu beliau pun mengajarkan dan mewariskannya kepada murid-muridnya. Bahkan beliau telah menyusun sebuah risalah tentang karangan-karangan gurunya dengan judul Risalah fi Asma al-Mu'allafat Ibn Taimiyyah yang mencapai 330 judul (Sanhuti: 27). Peran besarnya dalam mempopulerkan kebesaran dan pemikiran Ibn Taimiyyah ini digambarkan secara jelas oleh Ibn Hajar al-Asqalani, bahwa "Seandainya manaqib (riwayat keagungan) Ibn Taimiyyah sudah tidak ada lagi, dan yang tersisa hanya muridnya Syaikh Ibn Qayyim alJauziyyah saja yang telah menulis berbagai karya bermanfaat bagi orang yang pro dan kontra, maka hal itu sudah cukup untuk menunjukkan kebesaran posisinya" (Jauziyah, 1983: 6) .

Selama berjuang dengan gurunya, beliau banyak mengalami 
penderitaan sebagaimana yang telah dialami gurunya. Beliau ikut disiksa dan dipenjara bersama gurunya dan baru dibebaskan setelah gurunya meninggal dunia. Ketika di dalam penjara, beliau selalu menyibukkan diri dengan membaca al-Qur'an, tadabbur, dan tafakkur sehingga Allah membukakan baginya kebaikan yang banyak (Awad: 100-109).Ibn Qayyim juga banyak mencetak ulama-ulama besar dari ilmu yang dimilikinya. Di antara mereka adalah (Jauziyyah: xxiv-xxv): Al-Imam al-Hafiz Zain al-Din Abu al-Faraj 'Abd al-Rahman ibn Ahmad ibn Rajab alBaghdadi al-Dimasyqi al-Hanbali yang dikenal dengan Ibn Rajab. Beliau adalah seorang ulama pengikut Imam Hanbali, ahli di bidang hadis, fiqh, dan sejarah. Wafat pada tahun $795 \mathrm{H}$. Al-Hafiz 'Imad al-Din Abu al-Fida Isma'il ibn 'Umar ibn Kasir al-Basrawi al-Dimasyqi al-Syafi'i. Ahli di bidang tafsir, hadis, dan sejarah. Dua di antara karyanya yang tidak asing adalah Tafsir Ibn Katsir dan al-Bidaryah wa al-Niharyah. Wafat pada tahun 774 H. Al-Hafiz Syams alDin Abu 'Abd Allah Muhammad ibn Ahmad ibn 'Abd al-Hadi ibn 'Abd alHamid ibn 'Abd al-Hadi ibn Yusuf ibn Muhammad ibn Qudamah al-Maqdisi al-Jama'ili al-Salahi. Ahli di bidang fiqh dan hadis. Wafat pada tahun 774 H.AlImam al-Hafiz Syams al-Din Abu 'Abd Allah Muhammad ibn 'Abd al-Qadir ibn Muhy al-Din 'Usman ibn 'Abd alRahman al-Nabilisi al-Hanbali. Wafat pada tahun 797 H.Kedua anak beliau, yaitu Syaraf al-Din 'Abd Allah, menggantikan ayahnya mengajar di sekolah al-Sadriyyah yang kemudian wafat pada tahun 756 H. Dan, Burhan al-Din Ibrahim, ahli di bidang figh dan bahasa. Ia wafat pada tahun $767 \mathrm{H}$. 'Ali 'Abd al-Kafi ibn 'Ali ibn Tammam al-
Subki Taqiy al-Din Abu al-Hasan.AlImam al-Hafiz Muhammad ibn Ahmad ibn 'Usman ibn Qiyam al-Zahabi alTurkmani al-Syafi'i. Dia memiliki banyak karya di bidang hadis dan lainlain.Muhammad ibn al-Khudari alGhazi al-Syafi'i. Nasabnya sampai kepada Zubair ibn 'Awwam r.a.AlFairuzabadi. Dia adalah Muhammad ibn Ya'qub al-Fairuzabadi al-Syafi'i.

\section{Riba dan Bunga Bankdalam Pandangan Ibn Qayyim}

Dalam menjelaskan konsep riba dalam pandangan Ibn Qayyim maka perlu kita jelaskan dulu hikmah perbedaan antara jual beli barang sejenis dan jual beli barang yang tidak sejenis. Dalam konteks riba. Menurtnya "ungkapan diharamkan menukarkan satu mud biji gandum basah dengan satu mud biji gandum yang sama di tambah segengam, dan sebaliknya dibolehkan menukarkan dengan segenggam biji gandum kering (Jauziyyah: 103). Menurut Ibnu Qayyim,riba dibagi menjadi dua macam, pertama riba jali, (jelas) dan kedua, adalah riba khafi, (samar).Ribajali adalah riba nasi'ah, sedangkan riba khafi adalah riba fadl. Riba jali diharamkan karena mengandung kemudharatan besar, sementara riba khafi adalah diharamkan karena menuju jalan riba jali, atau diharamkan karena menjadi maqs, dan diharamkan yang kedua sebgai zari'ah, langkah antisipatif (Jauziyah: 103).

Adapan riba jali, disebut dengan riba nasi'ah karean akar historisnya, riba ini adalah riba yang dipraktekan dalam masa jahiliyyah, dalam riba ini terjadi mekanisme interst dalam pokok pinjaman, setiap kali ada penjadwalan hutang setiap kali itu pula debitor 
memberikan bunga pokok pinjaman. Praktek inilah yang menjadikan debitor tidak mampu melunasi hutanghutangnya, ini berarti debitor mengambil harta saudaranya dengan cara batil. Sedangkan dalam hal yang sama debitor dalam kondisi keterpurukan. Maka Allah dengan sikap Rahman-Nya mengharamkan praktek semacam ini, mengutuk pelaku, penulis dan kedua belah saksinya.Ibn Qayyim menjalskan bahwa Rasio dan persepsi manusia terbatas dalam mengunkapkan rahasia persyari'atan hukum Allah, penegasan itu terlihat dari pengakuan dan kelemahan itu menunjukan Sikap Ibn Qayyim sebgaia seorang yang tawadu' yang dalam bahasa Al-Quran disebut dengan alRasikh fi al-Ilmi, isitilah khafi dan jali yang digunakan oleh Ibn Qayyim dalam hal ini merupakan Istilah baru pada zamannya. Dan tidak diketemukan selain dia dalam menggunakan istilah jali dan khafi ini. Dalam hal ini penyebutan Istilah baru adalah upaya Ibn Qayyim dalam memberikan nuansa baru dengan pertama menyebutkan istilah baru. Dan pandangan baru, Ibn Qayyim sangat hati-hati dalam mendefiniskan riba jali, dalam hal ini pandangan seorang ulama Ibn Hambal ia pakai sesungguhnya riba itu adalah seseorang yang memiliki hutang lalu dikatakan kepadanya, apakah akan melunasi atau membayarnya lebih? Maka jika tidak mampu melunasi maka dia harus memberikan ziyadah, kepada pokok harta karena penundaan waktu yang diberikan, kepdanya, Allah menjadikan riba sebgai lawan dari shadaqah. Dalam sebuah hadis Nabi:Dari Ibnu Abbas, Dari Usamah bin Zaid bahwa Nabi Muhammad bersabda "Bahwa riba itu hanya ada pada nasi'ah".
Menurut Ibn Qayyim, siggt hasr yakni innam, pada hadis tersebut menunjukan sigt hasr kamilah yang berarti riba yang sempurna hanya riba nasi'ah. Sedangkan apabila membahas riba khafi yang sebenarnya tak lain adalah riba fadl, maka menurut Ibnu Qayyim pengharamanya adalah melalui (sadd al-zari'ah), yakni salah satu kaidah ushul fiqh yang berarti menutup jalan. Atau dalam bahasa kerennya adalah langkah preventif, karean akan menuju riba nasi'ah. Hal ini dilandasi oleh Ibn Qayyim dengan memperlihatkan dalil yang dikemukakan oleh Abi Sa'id alKhudri, dari Nabi Muhammad Saw:"Janganlah Kalian melakukan transaksi satu dirham dengan dua dirham, sesungguhnya aku kahwatir kalian akan melakukan al-rima, yakni alriba" (Jauziyyah: 104).Jadi menurut Ibnu Qayyim pelarangan riba fadl atau riba khafi adalah karena adanya kekhawatiran akan terjerumus pada riba nasi'ah hal itu akan terjadi apabila satu dirham ditukarkan oleh dua dirham. Menurut Muslihudeen dalam mengomentari hadis tersebut, kata 'khawatir' merupakan dalil yang jelas mengenai fatwa Nabi mengharamkan cara dagang tersebut, sedangkan Ibn Qayyim menjelaskan lebih lanjut bahwa ada beberpa komoditi yang diharamakan dengan menggunakan riba fadl, dan para ahli fikh sepakat terhadap enam komoditi tersebut apabila ada kelebihan, dalam satu jenis. Tetapi untuk diluar enam komoditi tersebut mereka berbeda pendapat hebat. Mereka berdalih bahwa sebenrnya dalam riba, metodologi keharamannya berdasarkan qiyas adalah metodologi illat yang lemah, sedangkan menurut Imam Syafi,i dan Imam Ahmad, yang 
haram dalam segi makanan saja, menurt Ibnu Qayyim pendapat ini yang paling kuat (Jauziyyah: 104).

Keharaman yang dalam pendapat Ibn Qayyim merupakan penjelma'an dari sebuah kaidah ushul yang berbasis pada (sadd al-zari'ah) suat saat bisa dibolehkan karena adanya kemaslahatan. Atau karena sudah menjadi keharusan sebagai sebuah kebutuhan masyarakat. Ketika menimbang adanya kebutuhan itu yang tercermin dan berkaitan dengan maqashid asy-syar'iyyah, maka pendapat Ibn Qayyim membolehkan riba fadl karean konsekuensi tersebut. Ibnu Qayyim berpandangan haram riba fadl harus melalui mekanisme dan mengikuti pandangan masyarakat. Sehingga acuan pandangan masyarakat harus merujuk pada maqashid syari'ah. Hal ini juga dikaji dari sisi kaidah fiqh:

\section{الحاجة العامة والخاصة تنزل منزلة الضرورة}

Artinya:

"Kebutuhan umum atau khusus menduduki posisi darurat".

Kebutuhan vital yang bersifat umum atu khusus, mempunyai pengaruh dalam perubahan ketetapan hukum, sebagaimana halnya darurat. Kebutuhan pokok dapat merubah status hukum yang semula dilarang menjadi dibolehkan. Kebutuhan umum (al-hajjaj am-mah)ialah kebutuhan yang semua orang memerlukannya dalam konteks seprti pertanian, perdagangan, politik dan hukum, sementara kebutuhan khusus, (al-hajjah al-khassah) merupakan kebutuhan sekelompok orang, seperti penduduk sebuah desa atau tenaga ahli tertentu, atu kebutuhan seorang individu tertentu (Zuhaily: 284-285).
Berdasarkan teori al-hajjah
tersebut menurut kalangan ulama
Hanafiyyah mendaptkan pinjaman dari sebuah keuntungan. Dalam hal ini kesamaan antara Ibn Qayyim dengan ulama kalangan Hanafiyyah adalah dengan menggunakan tori al-hajjah dalam kontek melegalkan riba fadl. Selanjutnya, Ibnu Qayyim menekankan bahwa dalam hal ini, tujuan-tujuan pokok (al-maqashid harus menjadi sebuah dasar pengambilan dan letaknya memang dalam kondisi darurat.

Banyak relevansi di masa amendatang bagi pemikiran Ibn Qayyim tentang riba ini, Ibn Qayyim menyatakan riba jali diharamkan karena mempunyai kemudharatan yang besar, pelarangan sebagi tujuan (al-maqashid) sedangkan riba khafi dilarang karenalangkah antisipatif (shadd azzari'ah) bagi riba jali, yang pertama harus dalam kondisi yang darurat dan yang kedua dalam kondisi yang al-hajjah, (membutuhkan), dia menekankan sebab dilarangnya sebuah riba adalah karena tidak sesuai keadilan dan ada perilaku ekploitasi dan monopoli, kalau begitu setiap transaksi yang mengandung ketiga unsur tersebut pasti dapat dikatagorikansebgai transaksi ribawi, sebaliknya transaksi pinjam meminjam atau istilahnya "perilaku ekonomi" yang mengedepankan nilai-nilai ekonomi dan keadilan serta terhindar dari eksploitasi dan monopoli bisa dikatakan bebas dari riba, konsep pemikiran demikian akan memberikan nuansa baru dalam kajian ekonomi Islam kontemporer baik konvensional maupun Islam.

Pemahaman riba yang lebih fleksibel sebagamaina yang telah 
diungkapkan oleh Ibn Qayyim akan membawa dampak lebih baik dengan adanya perkembangan perbankan Islam, sebagaimana diketahui bahwa pada awal abad 20-an perbankan Islam, yang dalam diskusi ini disebut dengan bank syari'ah adalah semcam diskusi teoritis, belum ada langkah nyata yang dilakukan untuk mengimplementasikan gagasan tersebut, telah muncul kesadaran bahwa bank Islam adalah upaya solutif terhadap ekonomi untuk mewujudkan kesejahteraan sosial yang bebas dari bunga, aktualisasi bank Islam atau syari'ah sulit berkembang karena kuat lajunya gerakan bank konvensional dalam bisnis di negaranegara maju dan berkembang atau dunia ketiga.

Gagasan untuk mewujudkan bank syari'ah semakin menguat dan mengkristal setelah gagasan tersebut dibicarakan dalam pertemuan menteri luar negeri negara-negara anggota organisasi konferensi Islam (OKI) di Karachi, Pakistan pada bulan Desember 1970 (Antonio, 1999: 58). Dalam konferensi tersebut memutuskan untuk membuat lembaga yang disebut dengan Islamic Devolepment Bank (IDB) pad atanggal 23 April 1973, lembaga ini dinyatakan berdiri secara efektif setelah dipenuhinya secara ketentuan dalam anggaran dasar mengenai penyerahan Instrument of Ratification oleh negaranegara anggota yang pada saat tersebut berjumlah 22 negara termasuk Indonesia. Upaya memunculkan lembaga (IDB) ini didasarkan bahwa bunga bank yang ditimbulkan transaksi simpan meminjam dalam bank konvesional adalah termasuk riba, sebagaimana dilarang dalam Islam (Zuhri: 155).
Berdirinya IDB telah memotivasi banyak negara Islam untuk mendirikan lembaga keuangan syari'ah, untuk itu komite Ahi IDB pun berkerja keras menyiapkan panduan teknis tentang pendirian dan peraturan, serta pengawasan bank syari'ah. Pada akhir tahun 1970-an dan memasuki awal 1980-an bank-bank syari'ah bermunculan di Mesir, Turki, Senegal, Guinea, Denmark, Inggris, dan lain sebagainya.

Bank Islam yang di Indonesia disebut juga dengan bank syari'ah, merupakan lembaga keuangan yang memebrikan kredit dan jasa-jasa dalam lalu lintas pembayaran serta beredarnya yang pengoperasiannya disesuaikan dengan prinsip-prinsip Islam atau syari'at Islam (Sumitro, 1996: 5). Didirikan bank Islam pada dasarnya untuk mempromosikan dan mengembagkan aplikasi dan prinsipprinsip keuangan, perbankan, dan bisnis-bsinis lain yang terkait, prinsip utama yang dianut oleh bisnis ini adalah: prtama, larangan riba dalam berbagai bentuk transaksi.Kedua, menjalankan bisnis dan aktifitas perdagangan yang berbasis pada perolehan yang sah menurut syari'ah.Ketiga, menunaikan zakat.Keempat, menghapus monopoli yang terjadi di pasar bebas, dan terlaksananya takaful ijtima'. Dalam menghidari terjadinya praktek bunga, bank Islam melakukan dengan cara prinsipprofit sharing (bagi hasil) salah satu produk perbankan yang mengacu pada hal tersebut adalah konsep mudharabah.Istilahmudharabah di kalangan mazhab Hanafiyyah, Malikiyah dan Hanbillah,lebih disebut dengan akad mudharabah, jika di 
kalangan Syafi'iyyah dan Malikiyyah disebut dengan istilah qirad (Zahari: 160). Menurut Ibnu Taimiyyah, para ahli hukum Islam menyatakan keabsahan mudharabah dengan menyandarkan kepada salah satu hadis nabi Muhammad yang otentik (Saeed: 52). Ibnu Hazm salah satu pediri mazhab Zhairi menyatakan bahwa setiap pasal fikih mempunyai dasar dalam al-Quran dan Hadis kecuali mudharabah, kita tidak menemukan dasar apapun mengenai itu (alSyaukani, tt: 267), sedangkan menurut Sarkashi (w. 483/1090) ahli kukum dalam kalangan Imam Hanfi menyatakan bahwa mudharabah diperbolehkan karena orang-orang memerlukan kontrak jenis ini (alSarakhis 1983: 19),sedangkan menurut pendapat Ibnu Rusyd, ahli hukum Maliki, mudharabah merupana konsensi khusus, walaupun secara ekplisit tidak nampak di dalam al-Quran dan Hadis, mudarabah merupakan sebuah tradisi yang diperbolehkan dan dipraktekkan oleh orang-orang Islam, asosiasi komersial ini muncul secara kontinyu sejak periode awal Islam.

Sebagaiman telah dijelaskan bahwa kerugian yang timbul dari usaha mudharabah ditanggung oleh pemilik modal, kalau begitu, karena bank sebagai pihak pemberi modal, maka berdasarkan prinsip ini jika terjadi kerugian banklah yang menangungnya, sedangkan pihak pengelola dana (mudarib) hanya rugi dari segi waktu, tenaga, dan upah yang didapatkan. Kemungkinan tersebut adalah teoritis belaka, baik dalam latar belakang ekonomi maupun empiris. Karena bank telah memberikan pinjaman modal kepada pengusaha lain yang berhasil, baik berbentuk mudharabah atau lainya, kerugian dapat ditutupi dari keuntungan tersebut (Siddiqi, 1983: 24). Dalam permasalahan yang ada dalam mudharabah, pihak pemodal, investor atau bank tidak diperbolehkan mengelola atau bekerja dengan para pengelola, maka syarat tersebut tidak sah, sebab pemodal, investor tidak berhak mengelola harta yang telah dileburkan dalam perseoran. Walaupun demikia, pegelola (mudharib) yang terikat dengan kontrak yang telah disepakati oleh pemodal ia tidak boleh menyimpang dari kesepakatan tersebut. Dalam pandangan perbankan keberhasilan dengan menjadi tolak ukur yang penting bagi keberhasilan mereka. Dalam konsep mudharabah ini anatara mudharob dan pemodal menjadi sangat penting adanya kejujuran, dan amanah antara keduanya, maka dengan sistem tersebut sistem bunga bank dalam perbankan konvensional dapat dihindari.

Para ulama shalaf dan khalaf menyepakati adanya keharaman tentang riba, perbedaan pendapat muncul di kalngan ulama khalaf(moderen), yang menjadi permaslahan adalah apakah bunga bank yang dilakukan oleh bank konvensional adalah termasuk riba, dalam kajian seterusnya adalah ada dua pendapat yang bergerak tentang hal tersebut, yaitu kaum modernis dan neorevivalis.Kalangan modernis adalah Fazlur Rahman, Muhammad Asad, Sa'ad An-Najjar dan Abd Mun'in alNamir, menerpakan aspek moral dalam mengesampingkan legal formal riba itu sendiri, menurut mereka, larang riba adalah jika penetapannya dalah ketidakadilan, sesuai dengan pernyatan al-Quran "la tazlimu wala tuzalamun", hal 
tersebut juga dapat ditemukan dalam pandangan ulama terdahul semacam AlRazi, Ibn Qayyim al-Jauziyah dan Ibnu Taimiyyah (Saeed: 41).

Menjadi sangat menarik dengan kenyatan tersbut bahwa ada kesinambungan antara riba dan perkembangan bank Islam, serta pandangan riba dalam pemahaman Ibn Qayyim al-Jauziyyah.

\section{Kesimpulan}

Riba dalam pandangn Ibn Qayyim ada dua:riba jali, dan ribakahfi, dalam pandangan ulama lainya disebut dengan riba nasi'ah sedangkan khafi disebut dengan riba fadl. Menurtnya riba jali diharamkan karena mengandung kemudharatan besar, sementara riba khafi diharamkan karean merupakan media dari adanya riba jali, diharamkan pertama karena sebagi maksud, dan diharamkan kedua apabila sebgai shadd zari'ah langkah antisipatif.

Riba khafi diharamkan karena kekhawatiran akan terjerumus dengan adanya rba jali, dan hal itu bisa terjadi apabila satu dirham ditukar dengan dua dirham, Ibn Qayyim memang tdak jelas dalam mempraktekkan riba khafi, tetapi ia mengatakan bahwa riba jenis ini ada 6 komotidi yang disebutkan dalam hadis dan dia menjelaskan pengharamnnya adalah langkah antisipatif.

Jika dilihat semacam itu, maka jikakita dekati dengan pandangan Ibn Qayyim yang menyatakan bahwa riba jali bisa ditolerir dengan kondisi darurat dan riba khafi dalam kondisi hajat, membutuhkan, demikian pula pandangan bahwa transaksi yang bebas bunga adalah transaksi yang mengedepankan nilai-nilai keladilan, menghindari eksploitasi, dan menjauhi monopoli, jauh ke depan pemikiran ini mempunyai implikasi:pertama, memperkuat praktek perbankan Islam yang sudah berjalan.Kedua, menetralsir pendapat-pendapat ekstrim terhadap praktek perbankan konvensional.Ketiga, mencermati adanya beberpa kritikan dari perbankan Islam yang dinilai masih lemah dan tidak sepenuhnya memegang prinsip profit dan propertest dan terbebas dari bunga, maka pemikrian Ibn Qayyim tersebut sebagai tawaran baru dalam upay amembangun sistem ekonomi Islam yang benar-benar terbebas dari sistem bunga, dalam mengimplementasikan pemikiran tersebut dibutuhkan penelitian yang lebih mendalam dalam penelitianpenelitian mendatang.

\section{DAFTAR PUSTAKA}

Awad, Mahmud. 2002. Para Pemberontak di Jalan Allah, Ibn Hazm, Ibn Taimiyyah, Rifa'ah al-Tahtawi, Jamaluddin al-Afghani, Abdullah alNadim, terj. Alimin Jakarta: Cendikia Sentra Muslim.

Al-Jauziyyah, Ibnu Qayim. I'lam alMuwaqqi'in, Beirut: Dar al-fikr. 2004. Kunci Kebahagiaan, Terj. 'Abd al-Hayy al-Katani. Jakarta: Akbar Media Eka Sarana. 1998. Petunjuk Memahami Nabi saw. Menjadi Hamba Allah Teladan dalam Berbagai AspekKehidupan.Terj. AchmadSunartodanAunurRafiq Jakarta: Robbani Press. 1983. al-Manar al-Munif fi alShahih wa al-Dha'if Beirut: Dar alKutub al-Ilmiyyah. 
Al-Sanhuti, Muhammad Anwar Yasin. 2001. Atawa, Fauzi. 1988.Al-Iqtishad wa al-Mal fi alIbn Qayyim Berbicara tentang Tuhan, Terj. Romli dan Heri. Jakarta: Mustaqim.

Al-Imad, Abu al-Falah 'Abd al-Hayy ibn Ahmad ibn Muhammad ibn. 1987. Syazarat al-Zahab Fi Akhyar Man Zahab. Beirut: Dar al-Kutub al-Ilmiyyah.

Al-Dimasyqi, Abu al-Fida ibn Kasir. 1987. AlBidayah wa al-Nihayah. Beirut: Dar al-Kutub al-Ilmiyyah.

Asan, Hasan Ibrahim. 1989.Sejarah Kebudayaan Islam, terj. Djahdan Humam. Yogyakarta: Kota Kembang. Tasri al-Islami wa al-Nazm wa alWadi'iyyah, Bairut: Dar al-Fikr.

Ilamundin, Muhammad. 1995, Insurance and Islamic Law. Delhi: Markaz Maktab Islami.

Munthari, Murtadhi. 1995.Al-Riba wa al Tamim, Terjemahn Irwan Kurniawan, Asuransi dan Riba. Bandung: Pustak Hidayat.

Ridha, Muhmaad Rasyid. 1374. Tafsir Almanar.Mesir: Matba'ah Muhammad Ali Sahib wa Abduh.

Nasution, Harun. 1985. Islam Ditinjau dari Berbagai Aspeknya.Jakarta: UI Press. 